Article

\title{
Toward Human-Centered Urbanization? Housing Ownership and Access to Social Insurance Among Migrant Households in China
}

\author{
Christine Wen ${ }^{1, * \mathbb{D}}$ and Jeremy L. Wallace ${ }^{2}$ \\ 1 Department of City and Regional Planning, Cornell University, Ithaca, NY 14853, USA \\ 2 Department of Government, Cornell University, Ithaca, NY 14853, USA \\ * Correspondence: hw495@cornell.edu
}

Received: 5 June 2019; Accepted: 26 June 2019; Published: 28 June 2019

check for updates

\begin{abstract}
For the past few years, China's urbanization policy has focused on expanding welfare and affordable housing for rural migrants so as to encourage them to put down roots in the city. The international literature disagrees on the relationship between homeownership and welfare-whether the former is a substitute for or a consequence of the latter. Using multilevel logistic regression on a 2015 nationally representative survey, this paper explores the determinants of housing ownership among China's rural migrant households in their city of residence, focusing particularly on access to urban social insurance. The results show that institutional ties to the city such as enrollment in local pensions and health insurance are associated with higher likelihood of homeownership. This paper argues that policy interventions should target the social security system, as rural migrants are likely unwilling or unable to invest in urban housing due to the increased risk and precarity they typically experience. The findings also suggest that to make urbanization more sustainable, the government should aim at making cities more family-friendly, expanding alternatives to employment-based social insurance schemes, and targeting efforts on interior cities in migrant-sourcing provinces that pose fewer barriers to permanent settlement.
\end{abstract}

Keywords: urbanization; urban China; rural migrants; homeownership; social insurance

\section{Introduction}

Rural migrants in China, now numbering approximately 286 million, have been and remain on the whole institutionally and economically disadvantaged. They are constrained by the household registration or "hukou" system in their access to housing and welfare in the city [1,2]. The hukou system was a socialist planning instrument that moored people to their places of official registration-agricultural or non-agricultural, local or non-local — for the purpose of resource allocation and job assignment, acting as a key component of a system characterized by a sharp urban-rural divide in terms of economic production and welfare arrangements [3]. Furthermore, it has survived through four decades of marketization to continue defining citizenship [4].

Yet despite the persistence of the hukou system, reforms to the housing and welfare system since the late 1990s have opened up more avenues to urban settlement for rural migrants. Previously under the planned socialist economy, urban experiences were dominated by the "iron rice bowl" model of secure employment and housing, sponsored by the state through work units and reserved exclusively for urban hukou holders. The model has now been replaced by a social security system more befitting the market economy-one that is based on a combination of individual payment, employer contribution, and state provision [5]. Partially de-linked from hukou and residency status, urban social insurance has become more accessible to rural migrants. Eligibility for employment-based 
insurance depends more on the specifications in the working contract than hukou status [6]. While separate residency-based schemes exist for urban versus rural hukou-holders (with large disparity in benefits and payouts), progress is underway to combine them into one. The recent elimination of agricultural/non-agricultural distinction in the hukou status in most provinces also created new access to urban social insurance for local migrants. In general, however, rural migrants are still disadvantaged due to their low status in the labor market and the decentralized or localized administration of social welfare. Similarly, even though the commodification of housing has rendered hukou status less critical to acquiring urban housing, scholars generally agree that the system's legacy contribution to inequality and continued hukou-based discrimination in access to subsidized housing are major factors behind low homeownership rate among rural migrants.

Many argue that the large volume of "floating" people-those who are dislocated from their permanent residence in rural origins and unable to settle down in destination cities-is the main roadblock for China's sustainable urbanization [7]. Policymakers in China have since responded to these concerns with a new developmental strategy that seeks to include more rural migrants in the urban welfare system and expand affordable housing options, with the expectation that they would have an easier time settling down in the city. There is little consensus in international scholarship about the relationship between welfare access and housing ownership. In some contexts, households purchase homes as a form of security to compensate for low levels of welfare [8]. On the other hand, being included in the welfare system signifies assimilation/integration for (im)migrants and has been linked to higher likelihood of permanent settlement and housing purchase. In the Chinese context, researchers debate about the changing impact of institutional factors relative to individual factors in predicting homeownership. The questions that concern us are: What is the connection between welfare access and housing ownership for migrant families? Should policies target the social security system or the housing market?

This paper analyzes the relationship between enrollment in urban social insurance and homeownership at the household level, using a sub-sample of rural migrant households from the 2015 China Household Finance Survey (CHFS) conducted by the Southwest University of Finance and Economics in Chengdu, China. We expect that homeownership does not substitute for welfare because rural migrants suffer from double disadvantage in both. They do not benefit from most urban-based pro-homeownership measures. Their generally poor financial situation-another consequence of China's long-standing institutional exclusion-means that much of the commercial housing market is out of their budget range. On the other hand, having social insurance in the city can mitigate the risks of migration and urban living. Otherwise, loss of job or home, major injuries and illnesses, and old age are just some of the things that could send migrants packing. Migrants are likely less willing or able to invest in housing when they are concerned about losing their urban livelihoods or having to save up money for contingencies [9]. For these reasons, we hypothesize a positive relationship between access to urban social insurance and homeownership. Our findings support this hypothesis. While the simultaneous structure of our data precludes strong causal inference, the policy implication of our analysis is clear: More insurance and welfare schemes should be made available to migrants without going through an employer.

\section{Literature Review and Argument}

\subsection{Housing and Welfare in International Cases}

The present study builds on two bodies of international scholarship. One is the research on homeownership and asset-based welfare. The other is classical assimilation and locational attainment theory from immigration studies. Due to different conceptualizations of housing and welfare citizenship, they hypothesize opposite relationships between homeownership and welfare participation.

The asset-based approach to welfare provision is a governance model based on the theoretical underpinning that housing is "a complex welfare good that supplements and mediates the flow of 
other welfare goods and services at the household level" ([8], p. 166) and what Torgersen (1987) termed "the wobbly pillar under the welfare state" [10]. Typically characterized by pro-homeownership policies, deregulated financial markets, and cutbacks in public spending, it spread from the UK to other advanced economies and led to a proliferation of market-oriented housing policies. This was joined by widespread neoliberal restructuring of welfare systems [11,12]. Individualization of risks through asset building is also prevalent in post-socialist transitional countries, as exemplified by high homeownership rates following privatization and commodification of public housing and dramatic reduction in public welfare budgets [13]. In developing countries, housing acquisition is a pivotal achievement for households facing inadequate welfare provisions. The normative implications of asset-based welfare are controversial, with some arguing for its ability to address serious deficits in welfare provision and others raising doubts about its sustainability and equitability $[14,15]$.

The empirical hypothesis, assuming an asset-based welfare system, is that at the household level, homeownership and participation in social security tend to be inversely related via a substitution or trade-off effect. Housing is an important component of welfare strategies for homeowners $[16,17]$. The state's retreat from redistributive welfare in the context of austerity makes housing acquisition even more imperative [18]. For aging societies, it is believed that housing wealth can be tapped to compensate for declining revenue following the retirement of baby boomers $[19,20]$.

The actual findings of these asset-based welfare system arguments are mixed and context-dependent, varying according to demographics, characteristics of the housing stock, financing mechanisms, and other factors [8]. For example, and in contrast to the trade-off effect hypothesis, Engelhardt [21] found that the increase in homeownership among the elderly in the US is almost entirely attributable to a rise in social security benefits. By contrast, Torricelli et al. [22] found that for Italy, homeownership is negatively associated with participation in pension schemes in spite of new incentives to participate and fluctuations in the housing market. Dewilde and Raeymaeckers [23] found evidence of both the trade-off effect and double disadvantage experienced by people without owned housing or pensions.

The literature on immigrant homeownership offers a contrasting perspective. Focusing on indicators of assimilation, these studies typically attribute variations in homeownership rates across and within immigrant groups to the degree of socioeconomic and institutional integration [24]. Empirically, citizenship status has been consistently shown to be a significant predictor for homeownership (e.g., [25]). In the US context, a person's legal status also matters for homeownership, as it affects access to educational opportunities, financial resources, and welfare benefits [26]. Furthermore, a longer duration of stay in host countries is also associated with a higher degree of assimilation and therefore higher likelihood of homeownership [27]. The consistent observation that these three factors-citizenship, legal status, and duration of stay-are significant for homeownership demonstrates the importance of the permanence, security, and inclusion for people from foreign origins. Since having social insurance contributes to these, the empirical hypothesis is that it should be associated with a higher likelihood of homeownership.

\subsection{Migrant Homeownership and Social Security Participation in China}

In China, there are large between-group differences in homeownership rates, one of which is that between urban local residents and rural migrants. The latter group is on average poorer and less familiar with city life and thus faces a difficult process of assimilation. Rural migrants are frequently compared to international immigrants with a semi-legal status: They are permitted to be in any city but not guaranteed all basic rights and services [28]. Most directly relevant to questions of housing ownership are two factors. The lack of local hukou almost always prevents migrants from accessing many affordable housing policies. Second, non-locals are much less likely to benefit from inter-generational transfer of housing ownership than are locals [29].

The debate on migrant homeownership largely revolves around the relative impact of institutional factors and socioeconomic factors. Some researchers argue that, as market transition theory predicts, individual life-cycle factors such as age, education attainment, and wealth are becoming more important. 
This is especially true in smaller cities where hukou status does not make as much of a difference [30]. In these locales with fewer institutional hurdles, migrants have adapted and found other ways to settle down [31,32]. Others maintain that institutional barriers are the main reason for migrants' low homeownership rate. Sampling migrants from six large Chinese cities, Fang and Zhang [33] demonstrated that not only does hukou status still have a decisively limiting effect on homeownership, but also access to urban health insurance is also significant. Using an earlier iteration of the CHFS survey, Wu and Zhang [34] evaluated a number of other institutions, such as urban social insurance access and rural land rights. They argue that that because a person's hukou status is tied up with these institutions, it still indirectly undermines the commitment of migrants to purchasing homes in the city.

Researchers have begun to isolate social security as an independent predictor of homeownership because urban social insurance has become accessible to wider segments of the rural migrant population [35]. To clarify, there are still separate schemes for urban and rural residents, employees and non-employees, public sector and private sector employees-the former of each pair of population groups privileged over the latter in benefit levels (Take pensions as an example: The disparity in income replacement rate is largest between urban civil servants and rural residents on basic pensions for peasants. The latter is so low $(30 \%-40 \%$ at best) that young people do not feel incentivized to participate, according to the IZA conference paper "Incentive problems in China's New Rural Pension program" (2011) by Lei, X., Zhang, C., and Zhao Y. Accessed from: http://conference.iza.org/conference_files/CIER2011/lei_x6071.pdf.). However, rural migrant workers may be entitled to urban, employment-based social security such as basic pensions and medical insurance for employees, unemployment insurance, work injury compensation, maternity insurance, housing provident fund, and other forms of welfare, depending on the specific arrangements with their employers. Any shortfalls on the employer's side are supposedly covered by the state. To address the problems of employer non-compliance with social insurance law that legally entitles workers and the low coverage of the irregularly-employed, the government has created residency-based schemes that depend primarily on individual contributions and state subsidies, which has been credited for dramatic increase in medical insurance coverage (China Labor Bulletin. Accessed from: https://clb.org.hk/content/china\%E2\%80\%99s-social-security-system, on 6/1/2019.). Enrolling in these, however, requires local hukou registration. Overall, the urban/rural divide in pensions and health insurance can be expected to decline with the eventual unification of urban and rural schemes. The state is also moving toward making public sector employees contribute more rather than rely entirely on government subsidies (State Council Decision on Reforming Pension System for Public Sector Employees (2015). Accessed from: http://www.mohrss.gov.cn/SYrlzyhshbzb/dongtaixinwen/ shizhengyaowen/201501/t20150114_148951.htm on 6/19/2019.). Geographical restrictions, on the other hand, remain in effect by means of the hukou system, at least at the time of survey: Migrants often encounter difficulties accessing and transferring benefits across localities [36].

These reforms have weakened or altered the link between the hukou system and social security. While some studies (e.g., [2]) found having a rural hukou status negatively affects participation in pensions, health insurance, and unemployment insurance, others found that the presence/absence of a labor contract outweighs hukou status in social insurance participation [6,36]. On the other hand, hukou status does affect other employment outcomes, such as educational disparity, labor market segmentation, and workplace discrimination $[37,38]$. These outcomes do affect access to welfare. Wang [39] argued that most migrants find employment in private firms, which are more likely than state-owned firms to evade compliance of social insurance mandates by informalizing employment. Migrants also tend to be less knowledgeable about welfare programs or less willing to participate in them [40].

The findings from research on the settlement intention of rural migrants suggest an answer as to the relationship between homeownership and access to welfare for this population group. Even though settlement intention is not exactly the same as homeownership, it is a precursor and a response: Migrants make house-buying decisions based on whether they intend to stay [41]. Research on 
migrants in mega-cities such as Beijing shows that settlement intention is not as high as expected [42,43]. Being excluded socially, spatially, and institutionally compels migrants to purchase homes anywhere but in the destination cities, even if they do not plan on moving into them soon [44]. Studies have consistently shown that stronger integration in host society contributes to stronger inclination to stay, whether it is better or more secure employment $[45,46]$, higher stakes of personal investment such as entrepreneurship or self-employment [47,48], or more sociocultural and emotional ties [48-50]. The causality appears to be two-way: People who intend to stay are also more motivated to seek out better housing conditions [51-53]. These findings suggest that assimilation outcomes may be more important than welfare-substitution effects for China's rural migrants, who are like foreigners in their own country due to the hukou system.

This paper takes advantage of the CHFS dataset's geographical scope and locational information to examine patterns of homeownership in the current city of residence. The literature review suggests that assimilation outcomes may be more important than welfare-substitution effects for China's rural migrants. We hypothesized that participation in a local social insurance scheme indicates institutional integration and therefore should be positively associated with homeownership. We also acknowledge that the alternative ordering of these events-homeownership preceding access to social welfare-exists, as those committed to a community enough to purchase a home are likely to overcome institutional barriers to access welfare. However, expanding access to urban social security is an easier policy intervention to consider than direct expansion of homeownership through non-market-based allocation of constructed housing. As such, we focus our analysis on the welfare-housing connection giving priority to the welfare factor.

\section{Materials and Methods}

The 2015 CHFS uses a three-stage random probability proportional to size sampling for counties (districts, county-level cities), residential communities, and households. This 29-province survey includes three separate datasets: The first contains household-level information on assets and wealth; the second contains individual-level demographic information including social insurance participation-for all individuals nested in the households; the third contains geographical information on the interview site, including the province, region, and urban/rural designation.

The sub-sample used in our analysis included households surveyed in urban areas only based on the information on urban/rural designation provided in the third dataset. Using information about hukou status in the second dataset, the "rural migrant" is a person whose hukou status is classified as rural or agricultural and registered in a location (county or district) that is different from the one where he or she regularly resides. Households in which none of the rural migrants reside in the survey city were removed from the sub-sample. To reflect the connectedness of decision-making by household members and the trans-locational nature of many migrant families, all households with at least one rural migrant were included, except for households in which none of the rural migrants reside in the survey city. The survey respondent by design was a long-term resident of at least six months. The final sample for the model had 1736 households with 6244 individuals.

Our analysis used multilevel binary logistic regression with robust errors on the dependent variable "homeownership". This dependent variable was coded 1 if the household owned a home in the survey city and 0 otherwise. In great majority of the cases, this property was also the household's primary residence. This measure for homeownership was chosen because it can be linked, location-wise, to the independent variables via the survey city. Individual social insurance participation was aggregated at the household level to match homeownership. We included only the household members residing with the survey respondent in the aggregate measure, since household members living elsewhere did not contribute to the household's institutional integration in the survey city.

The main set of explanatory variables was participation in social insurance, measured as the number of household members enrolled in pensions, health insurance, unemployment insurance, work injury compensation, maternity insurance, and housing provident fund. It was coded 1 or 0 
for each household member and summed at the household level. There was no empirical evidence or conceptual basis for reverse causality that homeownership leads to higher likelihood of social insurance participation for migrants [54].

At the individual level, "pensions" was coded 1 for a household member residing in the survey city if he or she was enrolled in any of the government's sponsored urban schemes. These could include - translated literally from Chinese-retirement pay for employees in government agencies and public institutions, basic pensions for urban employees, basic pensions for urban residents, new pensions for villages, or merged basic pensions for urban and rural residents. The last one was uncommon at the time of the survey as it was an experiment in reducing urban-rural disparity.

The binary variable for health insurance was coded 1 (at the individual level) if enrollment or registration in the primary type of health insurance (in the event that a person was enrolled in multiple schemes) was processed in the survey city and 0 otherwise, for all schemes and for all household members, regardless of residential location. Like pensions, health insurance schemes include public (state) healthcare, basic health insurance for urban employees, basic health insurance for urban residents, and so on. The most common scheme for rural migrants is called "new cooperative health insurance for villages". The number of people enrolled in other health insurance schemes, including commercial health insurance, was negligibly small to zero in the sub-sample.

Enrollment in residence-based health insurance typically requires local hukou registration. Rural migrants without access to basic health insurance for urban employees still need to rely on the inferior rural insurance. While getting reimbursement is possible for receiving care in a different city, there are many limitations (at the time of the survey). Reimbursement can only be processed in certain designated hospitals, and the amount of reimbursement is based on policies in the place where one is registered rather than the place where one receives care. This is the reason that only the location of registration for health insurance was considered: It makes a great difference on its own, and in the case of rural migrants, imparts information about the type of health insurance.

Other insurance schemes such as unemployment, compensation for work injuries, maternity, and housing are relatively minor compared to pensions and health insurance. For these variables, only household members living in the survey city were included in the aggregate household-level measure. At the individual level, enrollment in each scheme was coded 1.

We controlled for a set of variables to account for connections to localities. Engaging in agricultural production and enrollment in health insurance elsewhere indicate ties to rural origins. Since permanent or long-term migrants tend to migrate within the provincial borders $[55,56]$, the proportion of intraprovincial migrants in a household can be important. Households that are split in different locations are less likely to commit to settling down, so a binary variable was used to indicate split households. Some previous studies included "living with spouse" and "living with school-age children" but the results were inconclusive. Fang and Zhang [33] found that these are positively and significantly related to homeownership, while Wu and Zhang [34] found the opposite for children in megacities and no significance in the full model. One reason for this discrepancy, besides different model specification and sample selection, is that situations involving children in reality are extremely complicated because of China's education system and the hukou. Children at different ages may be more or less likely to reside with migrant parents, and it is unclear how that affects housing tenure. While parents may not purchase a house in the city if their children cannot join them, this does not imply that childless adults (also coded 0 for "living with school-age children") are less likely to purchase a house. Parents may also purchase a house in anticipation of transferring children to city schools in the future. Housing tenure decision by couples living together in the city also involves many different considerations at different points in the life course. For these reasons, we captured both "living with spouse" and "living with children" with a single binary variable denoting split families, with 1 indicating that one or more household members does not reside with the survey respondent.

Additionally, the model controlled for demographics, household income, and employment. Demographic variables included the age and sex of the household head, as well as the average 
education attainment for all adults in the household. Employment variables included the number of household members employed in the public sector, having a work contract, working a temporary or informal job, working as farmers, and self-employed. While employment status is related to social insurance participation, this does not preclude the distinct possibility of self-employed or informally employed individuals purchasing their own social (not commercial) insurance without the aid of an employer. The number of employees or "breadwinners" in the household was selected as a control variable.

Finally, the 'region' variable refers to the eastern, central, and western regions of China, designated 1 (baseline), 2, and 3, respectively. Different sources may group the northeastern provinces differently. According to the data usage manual of this particular survey, the eastern region includes Beijing, Tianjin, Hebei, Liaoning, Shanghai, Jiangsu, Zhejiang, Fujian, Shandong, Guangdong, and Hainan; the central region includes Shanxi, Jilin, Heilongjiang, Anhui, Jiangxi, Henan, Hubei, and Hunan; the western region includes Inner Mongolia, Guangxi, Chongqing, Sichuan, Guizhou, Shaanxi, Gansu, Qinghai, and Ningxia. This grouping is consistent with the generalization that eastern provinces are the most developed, followed by central provinces, followed by western provinces. Since it is not critical to the study to know which cities or provinces exhibit higher to lower homeownership rates, city-level and provincial-level variations as random effects, with the exception of city median housing price, which was calculated from the full sample.

\section{Results}

\subsection{Descriptive Analysis of Key Variables}

Table 1 shows descriptive information for the key variables. A comparison was made between mixed-status households and households consisting solely of rural migrants. It is clear that the latter was more advantaged across the board-housing ownership, education, income, secure employment, and social insurance participation. Of rural migrant households $22.6 \%$ owned housing in the survey city, compared to $52.5 \%$ for mixed-status households. Mixed-status households had much higher income-approximately 120,000 RMB yuan compared to only 77,000 RMB yuan for rural migrant households. These advantages were due to the presence of local residents and urban migrants in the household.

For employment and social insurance participation, we presented a modified measure that shows the proportion of households with at least one person working in the public sector, working informally, having health insurance, and so on. Subtracting from 1 produced the proportion of households without, for instance, any social insurance. Rural migrant households were more disadvantaged in terms of pensions, health insurance, and housing fund than unemployment insurance, work injury compensation, and maternity insurance, in comparison with mixed-status household. Of rural migrant households $68 \%$ were without pensions, and nearly that many had no health insurance for any household member-compared to less than $40 \%$ for mixed-status households.

Of mixed-status households $51.6 \%$ had at least one person working under a formal contract, compared to $34.7 \%$ for rural migrant households. Rural migrants were slightly more likely to be self-employed or worked as farmers. Mixed-status households were less likely to reside together and engaged more interprovincial migration, probably due to a combination of in-migrating and outgoing household members. Breaking down the data geographically shows that housing ownership was higher in central and western regions, which was expected as these are generally migrant-sourcing regions with less expensive real estate. These regions also, unsurprisingly, showed higher prevalence of intra-provincial migration. The more developed eastern region exhibited the highest level of social insurance participation but lowest rate of housing ownership. While social security coverage is better for rural migrant households in the eastern region than in the other two regions, the disparity between rural migrant households and mixed-status households was more severe proportion-wise. 
Table 1. Descriptive information for key variables.

\begin{tabular}{|c|c|c|}
\hline Key Variables & Rural Migrant & Mixed-Status \\
\hline Owns a home in city of residence ( $\%$ of households) & 22.6 & 52.5 \\
\hline \multicolumn{3}{|l|}{ Urban Social Insurance (\% of households) } \\
\hline \multicolumn{3}{|l|}{ At least one household member has ... } \\
\hline ... urban pensions & 31.5 & 64.5 \\
\hline ... local health insurance & 33.1 & 60.3 \\
\hline ... unemployment insurance & 23.6 & 38.6 \\
\hline ... work injury compensation & 26.6 & 40.3 \\
\hline ... maternity insurance & 19.5 & 35.1 \\
\hline ... housing provident fund & 15.1 & 33.9 \\
\hline \multicolumn{3}{|l|}{ Household Characteristics/Demographics } \\
\hline Age of household head & 37.4 & 40.0 \\
\hline Household head is female (\%) & 31.9 & 38.1 \\
\hline Household size & 2.76 & 3.86 \\
\hline Education among adults ( $3=$ junior high school; $4=$ senior high school) & 3.5 & 3.9 \\
\hline Mean household income & 77,156 & 120,080 \\
\hline \multicolumn{3}{|l|}{ Employment (\% of households) } \\
\hline \multicolumn{3}{|l|}{ At least one household member is ... } \\
\hline ... employed in the public sectors & 11.7 & 24.6 \\
\hline ... employed with a formal contract & 34.7 & 51.6 \\
\hline ... working a temporary job & 22.7 & 17.5 \\
\hline ... employed as a farmer & 0.7 & 0.4 \\
\hline ... self-employed & 22.0 & 20.6 \\
\hline \multicolumn{3}{|l|}{ Urban/rural ties, settlement (\% of households) } \\
\hline At least one intra-provincial migrant & 50.2 & 43.1 \\
\hline Split household & 8.5 & 29.7 \\
\hline Household engaged in agricultural production last year & 8.8 & 8.8 \\
\hline At least one household member has health insurance elsewhere & 62.8 & 64.1 \\
\hline$N$ & 1046 & 690 \\
\hline
\end{tabular}

Source: 2015 China Household Finance Survey.

\subsection{Regression Analysis of Housing Ownership}

Table 2 shows the coefficients and odds ratios from regression analysis. The sustained importance of hukou was evident in the results for percentage of local residents in the household and percentage of rural migrants in the household, which were, respectively, positively and negatively related to housing ownership. The positive and significant associations between age, education, household size, household income, and housing ownership agreed with established findings. These associations reflected the importance of life cycle and assimilation factors for housing ownership and have been universally demonstrated across many different contexts.

For social insurance participation, having urban pension and health insurance in the survey city contributed to housing ownership. One additional household member with pensions and health insurance was associated with a $37 \%$ and $17.3 \%$ likelihood increase for housing ownership, respectively. These associations were significant even after controlling for hukou status. On the other hand, no significant associations were found for unemployment insurance, work injury compensation, maternity insurance, and housing fund, although the positive directions (or signs) were as hypothesized. The results for social security confirmed the findings from earlier studies by Fang and Zhang [33], Wu and Zhang [34], and Huang et al. [30].

It is somewhat surprising that employment factors did not appear important. This agreed with the finding from Chen and Liu [48] that labor market status is not related to settlement intentions. However, running a partial model consisting only of employment variables changed the picture (table omitted due to space limit and available upon request). In the partial model, one more household member working in the public sector made the household 50\% more likely to own housing. Self-employment raised the likelihood of homeownership by $65 \%$. This agreed with existing literature arguing that entrepreneurship and self-employment contribute to stronger settlement intention by increasing contact with locals and foster a sense of belonging and commitment. Having a signed work contract raises the 
likelihood of homeownership, while working at a temporary job lowers it. The significance of these associations disappeared with the addition of hukou, demographic, socioeconomic, and social insurance variables. Fang and Zhang [33], by contrast, found a significant and positive relationship between a job with a contract and housing ownership, but none for age and education of the household head.

For the last group of variables, intra-provincial migration was associated with higher probability of housing ownership, as did co-habitancy of household members in the same city. Migrating within the provincial borders typically crosses lower barriers and shorter distance from home, which makes permanent settlement more feasible. Household members living together in the city increased the level of social and emotional attachment to that city. Conversely, having one's primary health insurance elsewhere decreased the likelihood of housing ownership in the survey city. Engaging in agricultural production was negatively associated with housing ownership in the city, but the effect was not significant. Geographically, housing ownership was $87 \%$ more likely for migrants living in the central region. In a single-level logistic regression without city and provincial random effects, both central and western regions were significantly associated with higher housing ownership, as expected for places with cheaper real estate. The coefficient for median housing price had the predicted sign (i.e., lower homeownership rate in more expensive cities) but was insignificant.

Table 2. Regression results for homeownership.

\begin{tabular}{|c|c|}
\hline Dependent Variable: Own a House in the Survey (Residence) City & Coefficient/Odds Ratio ( $p$-Value) \\
\hline \multicolumn{2}{|l|}{ Access to social insurance in the city of residence } \\
\hline \multicolumn{2}{|l|}{ Number of household members enrolled in ... } \\
\hline ... urban pension & $+0.370 / 1.447(0.011) * *$ \\
\hline ... local health insurance & $+0.173 / 1.188(0.000)^{* * *}$ \\
\hline ... unemployment insurance & $+0.187 / 1.206(0.307)$ \\
\hline ... work injury compensation & $+0.089 / 1.093(0.735)$ \\
\hline ... maternity insurance & $+0.015 / 1.015(0.906)$ \\
\hline ... housing provident fund & $+0.060 / 1.062(0.641)$ \\
\hline \multicolumn{2}{|l|}{ Household characteristics/Demographics } \\
\hline Percentage of household members with this city's urban hukou & $+2.507 / 12.273(0.000) * * *$ \\
\hline Percentage of rural migrants in the household & $-0.798 / 0.450(0.049)^{* *}$ \\
\hline Age of household head & $+0.027 / 1.028(0.000)^{* * *}$ \\
\hline Household head is female: $1=$ yes; $0=$ no & $-0.047 / 0.954(0.668)$ \\
\hline Household size & $+0.313 / 1.368(0.000) * * *$ \\
\hline Education attainment among adults & $+0.126 / 1.134(0.006)^{* * *}$ \\
\hline Household income (10,000 yuan) & $+0.008 / 1.008(0.053) *$ \\
\hline \multicolumn{2}{|l|}{ Employment } \\
\hline Number of employees in the household & $-0.277 / 0.758(0.426)$ \\
\hline Number of household members working in public sectors & $+0.025 / 1.025(0.864)$ \\
\hline Number of household members employed by a contract & $-0.357 / 0.700(0.330)$ \\
\hline Number of household members working temporary jobs & $-0.283 / 0.754(0.483)$ \\
\hline Number of household members working as farmers & $+0.983 / 2.673(0.292)$ \\
\hline Number of self-employed household members & $+0.236 / 1.266(0.484)$ \\
\hline \multicolumn{2}{|l|}{ Urban/rural ties (settlement) } \\
\hline Percentage of intra-provincial migrants in the household & $+0.665 / 1.924(0.001) * * *$ \\
\hline Split household: $1=$ yes; $0=$ no & $-0.675 / 0.509(0.000) * * *$ \\
\hline Engaged in agricultural production last year: $1=$ yes; $0=$ no & $-0.344 / 0.709(0.159)$ \\
\hline Number of household members with nonlocal health insurance & $-0.140 / 0.870(0.003)^{* * *}$ \\
\hline \multicolumn{2}{|l|}{ Region $($ eastern $=$ baseline) } \\
\hline $2=$ central & $+0.626 / 1.704(0.030) * *$ \\
\hline $3=$ western & $+0.198 / 1.125(0.691)$ \\
\hline Median housing price (10,000 yuan) & $-0.002 / 0.997(0.413)$ \\
\hline Province random effect & $1.70 \times 10^{-31}\left(\right.$ S.E. $\left.2.98 \times 10^{-30}\right)$ \\
\hline City random effect & 0.529 (S.E. 0.197) \\
\hline N & 1736 \\
\hline
\end{tabular}




\section{Discussion and Conclusions}

Both housing ownership and social insurance coverage for China's rural migrants has risen over the years and is increasingly disconnected with hukou status. Previous studies are inconclusive about which factors affect decisions about settlement and housing, and to what extent [57,58]. One reason for the disagreement is that they draw from different, localized samples. The present study takes advantage of a nationally representative survey conducted recently during a time marked by large strides forward in the area of social security. Our regression analyses show that social insurance participation is associated with higher likelihood of homeownership for rural migrant households after controlling for other contributing factors.

This result suggests that the locational attainment model as it is used in immigration studies is a viable framework for analyzing homeownership for China's internal migrants. The framework assumes the existence of persistent structural barriers between the migrant population and the host society as well as the importance of intra-group differences in personal resources-such as wealth and human capital—in determining housing outcomes. It hypothesizes that economic, social, and institutional integration of migrants positively influences their upward residential mobility. In our study, citizenship status, welfare access, and assimilation factors (i.e., socioeconomic and life-cycle characteristics of individuals and households) were found to be significant predictors for migrant homeownership. In addition, the fact that intraprovincial migrants were more likely to be homeowners also supports the assimilation view due to the greater cultural similarity and lower cost barriers between origin and destination. Furthermore, family separation was not conducive to settlement and housing ownership, which shows that lack of commitment to host city discourages housing purchase, as suggested by the international literature on immigrant homeownership. Expanding social insurance coverage not only helps the working adults but also supports other family members. For example, in China, children's eligibility to enroll in health insurance typically depends on the enrollment status of their parents. Since migrants still face limitations in receiving subsidized healthcare in their destination city, it makes sense that the locational restriction on accessing medical insurance benefits matters and shows up in the regression as a significant institutional barrier.

Based on these findings, we argued that rural migrants are often not committed to settling down in destination cities because their non-local and non-urban hukou status circumscribes their rights as welfare citizens and introduces a major source of precarity. If the goal for the government is to get more migrants settling down and buying homes in the city, policies should aim to expand social security for migrant workers and their families. This paper also echoes recent scholarship on the declining importance of the hukou system by considering other institutional factors. The reasoning is that since acquiring urban hukou is either impossible (in large cities) or not worthwhile (in small cities), it no longer enters into the equation of migrants' decision-making. There exist more flexible paths for migrants to achieve urban settlement by making use of both urban and rural resources. To answer the question empirically, however, time-series analysis is needed. The cross-sectional analysis in this paper only showed that families with urban hukou holders were advantaged in both housing and social security.

Like other post-socialist countries, the Chinese government pursued pro-homeownership policies to promote asset-based welfare that resulted in overall exceptionally high homeownership rate [59]. Migrants did not benefit as much from these policies. Policy interventions in the housing market for migrants are difficult, as recent studies on affordable housing reveal that migrants as a group make diverse housing choices [60]. Interventions in broadening social welfare provision, on the other hand, can contribute to livelihood improvement and allow migrants to better mobilize their own resources. Currently, the portability of social security benefits is better for intra-provincial migration, but procedures also exist for transferring them outside province, although cashing out typically requires a certain number of years of continuous, accumulated payments. This provincial border effect was exhibited in the regression result that intra-provincial migrants were more likely to own a home. In the years after the survey was conducted, there have been moves by the government to accelerate the 
merging of urban and rural residence-based social insurance and implementation of a single social security card that can be used anywhere in the country. Such improvement in geographical flexibility is a move in the right direction and can potentially broaden settlement options for migrants.

An unexpected finding was that employment-related factors did not matter in the presence of other more impactful variables. From the descriptive analysis, it appeared that the eastern region, which receives migrants, had the highest social insurance participation but lowest housing ownership. This could be a homeownership-welfare substitution effect, but the more likely explanations are that housing there was too expensive, and migrants did not plan on settling down. This disconnect between employment and housing may well be specific to the migrant population, though this requires further investigation. Liu and $\mathrm{Xu}$ [61] found that temporary migration is eastward where employment opportunities are, while permanent migration tends to be concentrated in the interior. From our regression analysis, which controlled for region, the influence of employment was captured by socioeconomic, settlement, and social insurance variables. This suggests that more options for pensions and health insurance should be made available to migrants without the need for employer contribution.

Overall, homeownership rate for rural migrants is still quite low, and social insurance coverage also has much room for improvement. Since this survey was conducted by residential grid sampling, migrants as a special group might be under-sampled since they tend to be more concentrated in enclave neighborhoods, where cheap rentals and informal jobs are common. This means that the numbers captured here was an estimate of the upper limit, and that the actual situation is worse. In the sub-sample for this study, the majority of rural migrant families were completely situated outside of state protection. The many progressive legislations on the social security front are being counteracted by the informalization of labor. Moreover, although migrants are legally entitled to access urban social insurance, they are prevented by other practical constraints, such as the precarious nature of employment, inability to afford the cost, or lack of knowledge about their rights and options. It has been demonstrated that public expenditure on social security for people with relatively low human capital generates high benefits for sustained economic growth [62]. Therefore, for the advancement of socially and economically sustainable urbanization in the coming years, this disadvantaged group needs to be the target for progressive reforms in social security and affordable housing reforms, whether or not any individual household can ever achieve urban homeownership.

Author Contributions: Conceptualization, C.W. and J.W.; Data curation, C.W.; Formal analysis, C.W.; Investigation, C.W.; Methodology, J.W.; Supervision, J.W.; Writing-original draft, C.W.; Writing—review \& editing, C.W. and J.W.

Funding: This research received no external funding.

Acknowledgments: The authors would like to thank the reviewers for their invaluable comments and Li Gan of the Southwest University of Finance and Economics for data access.

Conflicts of Interest: The authors declare no conflict of interest.

\section{References}

1. Logan, J.R.; Fang, Y.; Zhang, Z. Access to housing in urban China. Int. J. Urban Reg. Res. 2009, 33, 914-935. [CrossRef] [PubMed]

2. Wu, W.; Wang, G. Together but unequal: Citizenship rights for migrants and locals in urban China. Urban Aff. Rev. 2014, 50, 781-805. [CrossRef]

3. Chan, K.W. The household registration system and migrant labor in China: Notes on a debate. Pop. Dev. Rev. 2010, 36, 357-364. [CrossRef]

4. Solinger, D. Contesting Citizenship in Urban China; University of California Press: Oakland, CA, USA, 1999.

5. Huang, Y.; Guo, F. Welfare programme participation and the wellbeing of non-local rural migrants in metropolitan China: A social exclusion perspective. Soc. Ind. Res. 2017, 132, 63-85. [CrossRef]

6. Cheng, Z.; Nielsen, I.; Smyth, R. Access to social insurance in urban China: A comparative study of rural-urban and urban-urban migrants in Beijing. Habitat Int. 2014, 41, 243-252. [CrossRef]

7. He, C.; Chen, T.; Mao, X.; Zhou, Y. Economic transition, urbanization and population redistribution in China. Habitat Int. 2016, 51, 39-47. [CrossRef] 
8. Doling, J.; Ronald, R. Homeownership and asset-based welfare. J. Hous. Built Environ. 2010, 25, $165-173$. [CrossRef]

9. Cao, G.; Li, K.; Wang, R.; Liu, T. Consumption structure of migrant worker families in China. China World Econ. 2017, 25, 1-21. [CrossRef]

10. Torgersen, U. Housing: The wobbly pillar under the welfare state. Scand. J. Hous. Plan. Res. Suppl. 1987, 4, 116-127. [CrossRef]

11. Rolnik, R. Late neoliberalism: The financialization of homeownership and housing rights. Int. J. Urban Reg. Res. 2013, 37, 1058-1066. [CrossRef]

12. Belfrage, C. Towards 'universal financialization' in Sweden? Contemp. Politics 2008, 14, 277-296. [CrossRef]

13. Mandic, S. The changing role of housing assets in post-socialist countries. J. Hous. Built Environ. 2010, 25, 213-226. [CrossRef]

14. Izuhara, M. Reconsidering the housing asset-based welfare approach: Reflection from East Asian experiences. Soc. Policy Soc. 2016, 15, 177-188. [CrossRef]

15. Walks, A. Homeownership, asset-based welfare and the neighborhood segregation of wealth. Hous. Stud. 2016, 31, 755-784. [CrossRef]

16. Soaita, A.M.; Searle, B.A.; McKee, K.; Moore, T. Becoming a landlord: Strategies of property-based welfare in the private rental sector in Great Britain. Hous. Stud. 2017, 32, 613-637. [CrossRef]

17. Toussaint, J.; Elsinga, M. Exploring "housing asset-based welfare": Can the UK be held up as an example for Europe? Hous. Stud. 2009, 24, 669-692. [CrossRef]

18. Ronald, R.; Kadi, J. What ever happened to asset-based welfare? Shifting approaches to housing wealth and welfare security. Policy Politics 2017, 45, 173-193. [CrossRef]

19. De Decker, P.; Dewilde, C. Homeownership and asset-based welfare: The case of Belgium. J. Hous. Built Environ. 2010, 25, 243-262. [CrossRef]

20. Malpass, P. Housing and the new welfare state: Wobbly pillar or cornerstone? Hous. Stud. 2008, 23, 1-19. [CrossRef]

21. Engelhardt, G.V. Social security and elderly homeownership. J. Urban Econ. 2008, 63, 280-305. [CrossRef]

22. Torricelli, C.; Brancati, M.C.U.; Santantonio, M. Does homeownership partly explain low participation in supplementary pension schemes? Econ. Notes 2016, 45, 179-203. [CrossRef]

23. Dewilde, C.; Raeymaeckers, P. The trade-off between homeownership and pensions: Individual and institutional determinants of old-age poverty. Aging Soc. 2008, 28, 805-830. [CrossRef]

24. Alba, R.D.; Logan, J.R. Assimilation and stratification in the homeownership patterns of racial and ethnic groups. Int. Migr. Rev. 1992, 26, 1314-1341. [CrossRef]

25. Vono-de-Vilhena, D.; Bayona-Carrasco, J. Transition towards homeownership among foreign-born immigrants in Spain from a life-course approach. Popul. Space Place 2012, 100-115. [CrossRef]

26. McConnell, E.D. Hurdles or walls? Nativity, citizenship, legal status, and Latino homeownership in Los Angeles. Soc. Sci. Res. 2015, 53, 19-33. [CrossRef] [PubMed]

27. Mundra, K.; Oyelere, R.U. Determinants of homeownership among immigrants: Changes during the Great Recession and beyond. Int. Migr. Rev. 2017, 52, 648-694. [CrossRef]

28. Roberts, K. China's "tidal wave" of migrant labor: What can we learn from Mexican undocumented migrants to the United States? Int. Migr. Rev. 1997, 31, 249-293. [CrossRef]

29. Cui, C.; Geertman, S.; Hooimeijer, P. Access to homeownership in urban China: A comparison between skilled migrants and skilled locals in Nanjing. Cities 2016, 50, 188-196. [CrossRef]

30. Huang, X.; Dijst, M.; van Weesep, J.; Zou, N. Residential mobility in China: Homeownership among rural-urban migrants after reform of the hukou registration system. J. Hous. Built Environ. 2014, 29, 615-636. [CrossRef]

31. Yang, S.; Guo, F. Breaking the barriers: How urban housing ownership has changed migrants' settlement intentions in China. Urban Stud. 2018, 1-19. [CrossRef]

32. Tao, L.; Hui, E.C.; Wong, F.K.; Chen, T. Housing choices of migrant workers in China: Beyond the hukou perspective. Habitat Int. 2015, 49, 474-483. [CrossRef]

33. Fang, Y.; Zhang, Z. Migrant household homeownership outcomes in large Chinese cities-The sustained impact of hukou. Eurasian Geogr. Econ. 2016, 57, 203-227. [CrossRef]

34. Wu, L.; Zhang, W. Rural migrants' homeownership in Chinese urban destinations: Do institutional arrangements still matter after Hukou reform? Cities 2018, 79, 151-158. [CrossRef] 
35. Huang, X.; Dijst, M.; van Weesep, J.; Jiao, Y.; Sun, Y. Residential choice among rural-urban migrants after the hukou reform: Evidence from Suzhou, China. Popul. Space. Place 2017, 23, 1-18. [CrossRef]

36. Gao, Q.; Yang, S.; Li, S. Labor contracts and social insurance participation among migrant workers in China. China Econ. Rev. 2012, 23, 1195-1205. [CrossRef]

37. Demurger, S.; Gurgand, M.; Li, S.; Yue, X. Migrants as second-class workers in urban China? A decomposition analysis. J. Comp. Econ. 2009, 37, 610-628. [CrossRef]

38. Song, Y. What should economists know about the current Chinese hukou system? China Econ. Rev. 2014, 29, 200-212. [CrossRef]

39. Wang, Z. Social security for China's migrant workers. Int. Labor Rev. 2011, 150, 177-187. [CrossRef]

40. Xu, Q.; Guan, X.; Yao, F. Welfare program participation among rural-to-urban migrant workers in China. Int. J. Soc. Welf. 2011, 20, 10-21. [CrossRef]

41. Wu, W. Sources of migrant housing disadvantage in urban China. Environ. Plan. A 2004, 36, 1285-1304. [CrossRef]

42. Fan, C.C. Settlement intention and split households: Findings from a survey of migrants in Beijing's urban villages. China Rev. 2011, 11, 11-41.

43. Fan, C.C.; Sun, M.; Zheng, S. Migration and split households: A comparison of sole, couple, and family migrants in Beijing, China. Environ. Plan. A 2011, 43, 2164-2185. [CrossRef]

44. Zhan, Y. 'My life is elsewhere': Social exclusion and rural migrants' consumption of homeownership in contemporary China. Dialect. Anthropol. 2015, 39, 405-422. [CrossRef]

45. Zhu, Y.; Chen, W. The settlement intention of China's floating Popul. in the cities: Recent changes and multifaceted individual-level determinants. Popul. Space. Place 2010, 16, 253-267. [CrossRef]

46. Tan, S.; Li, Y.; Song, Y.; Luo, X.; Zhou, M.; Zhang, L.; Kuang, B. Influence factors on settlement intentions for floating population in urban area: A China study. Qual. Quant. 2017, 51, 147-176. [CrossRef]

47. Cao, G.; Li, M.; Ma, Y.; Tao, R. Self-employment and intention of permanent urban settlement: Evidence from a survey of migrants in China's four major urbanizing areas. Urban Stud. 2015, 52, 639-664. [CrossRef]

48. Chen, S.; Liu, Z. What determines the settlement intention of rural migrants in China? Economic incentives versus sociocultural conditions. Habitat Int. 2016, 58, 42-50. [CrossRef]

49. Du, H.; Li, S.-M. Is it really just a rational choice? The contribution of emotional attachment to temporary migrants' intention to stay in the host city in Guangzhou. China Rev. 2012, 12, 73-94.

50. Huang, X.; Liu, Y.; Xue, D.; Li, Z.; Shi, Z. The effects of social ties on rural-urban migrants' intention to settle in cities. Cities 2018, 83, 203-212. [CrossRef]

51. Xie, S.; Chen, J. Beyond homeownership: Housing conditions, housing support, and rural migrant urban settlement intentions in China. Cities 2018, 78, 76-86. [CrossRef]

52. Liu, Z.; Wang, Y.; Chen, S. Does formal housing encourage settlement intention of rural migrants in Chinese cities? A structural equation model analysis. Urban Stud. 2017, 54, 1834-1850. [CrossRef]

53. Zhou, J. The New Urbanization Plan and permanent urban settlement of migrants in Chongqing, China. Popul. Space. Place 2018, 24, 1-13. [CrossRef]

54. Wu, Y.; Xiao, H. Social insurance participation among rural migrants in reform era China. Asian Pac. Migr. J. 2018, 27, 383-403. [CrossRef]

55. Hu, F.; Xu, Z.; Chen, Y. Circular migration, or permanent stay? Evidence from China's rural-urban migration. China Econ. Rev. 2011, 22, 64-74. [CrossRef]

56. Su, Y.; Tesfazion, P.; Zhao, Z. Where are the migrants from? Inter- vs. intra-provincial rural-urban migration in China. China Econ. Rev. 2018, 47, 142-155. [CrossRef]

57. Liu, Y.; Deng, W.; Song, X. Influence factor analysis of migrants' settlement intention: Considering the characteristic of city. Appl. Geogr. 2018, 96, 130-140. [CrossRef]

58. Xu, Z.; Liu, Y.; Liu, K. Return migration in China: A case study of Zhumadian in Henan province. Eurasian Geogr. Econ. 2017, 58, 114-140. [CrossRef]

59. Wang, Y.P. From socialist welfare to support of home-ownership: The experience of China. In Housing and the New Welfare State: Perspectives from East Asia and Europe; Groves, R., Murie, A., Watson, C., Eds.; Ashgate: Aldershot, UK, 2007; Volume 3, pp. 127-154.

60. Gan, X.; Zuo, J.; Ye, K.; Li, D.; Chang, R.; Zillante, G. Are migrant workers satisfied with public rental housing? A study in Chongqing, China. Habitat Int. 2016. [CrossRef] 
61. Liu, Y.; Xu, W. Destination choices of permanent and temporary migrants in China, 1985-2005. Popul. Space. Place 2017, 23, 1-17. [CrossRef]

62. Zhang, M.; Zou, X.; Sha, L. Social security and sustainable economic growth: Based on the perspective of human capital. Sustainability 2019, 11, 662. [CrossRef] 